\title{
Ferti-irrigational impact of distillery effluent and Di-ammonium phosphate on the soil and growth characteristics of Egg plant (Solanum melongena L.)
}

\section{Sachin Srivastava*, A . K . Chopra and Chakresh Pathak}

Department of Zoology and Environmental Science, Gurukula Kangri University, Haridwar-249404 (Uttarakhand), INDIA *Corresponding author. E-mail: sachin.env@gmail.com

Received:September 7, 2012; Revised received:O ctober 9, 2012; Accepted:November 12, 2012

\begin{abstract}
A comparative study was conducted to assess the ferti-irrigational effect of Distillery effluent (DE) concentrations such as $10 \%, 25 \%, 50 \%, 75 \%$ and $100 \%$ along with control (Bore well water-BWW) and Di-ammonium phosphate (DAP) separately for the pot culture cultivation of Solanum melongena. The results revealed that DE concentrations had significant $(\mathrm{P}<0.001)$ effect on $\mathrm{EC}, \mathrm{Cl}^{-}, \mathrm{Mg}^{2+}, \mathrm{OC}, \mathrm{HCO}_{3}^{-}$, exchangeable $\mathrm{Na}^{+}$, available $\mathrm{K}^{+}, \mathrm{Ca}^{2+}$ TKN, available $\mathrm{P}$ and $\mathrm{SO}_{4}^{2-}$, whereas non-significant $(\mathrm{P}>0.05)$ effects were observed for water holding capacity (WHC) and bulk density (BD) of the soil. Irrigation with $100 \%$ concentration of $\mathrm{DE}$, increased $\mathrm{EC}(+63.46 \%), \mathrm{Cl}^{-}$ $(+292.37 \%), \mathrm{Mg}^{2+}(+1162.72 \%), \mathrm{OC}(+3763.63 \%)$, exchangeable $\mathrm{Na}^{+}(+264.29 \%)$, available $\mathrm{K}^{+}(+48.39 \%), \mathrm{Ca}^{2+}$ $(+815.74 \%)$, TKN $(+1449.18 \%)$, available $\mathrm{P}(+338.83 \%), \mathrm{SO}_{4}{ }^{2-}(+80.07 \%)$, while decreased $\mathrm{pH}(-17.85 \%)$ total bacteria $(-47.02 \%)$, fungi $(-52.17 \%)$ and actinomycetes $(-82.89 \%)$ in effluent irrigated soil. Application of diluted doses of DE significantly increased plant height, root length, chlorophyll content, leaf area, number of leaves, number of branches, number of flowers, fruit length, fruit diameter, fruit weight, number of fruit and crop yield of $S$. melongena, with the better results being obtained at a dilution of $50 \%$ of DE concentration in comparison to DAP and BWW.
\end{abstract}

Keywords: Agronomic characteristics, Distillery effluent, Di-ammonium phosphate, Solanum melongena, Soil characteristics

\section{INTRODUCTION}

The fresh water is becoming a declining resource in today's scenario. To tide over from this crisis, limiting its allocation is vivid in every water use sectors. Therefore with growing crisis of freshwater, there is a need to provide an alternate source, which could support and sustain production in proportion with growing demand of burgeoning population. A steady recession of fresh water distribution is evident in every water consumption sectors including agriculture where water is an integral component (FAO, 2003; Das et al., 2009).

With the exponential increase in the number of industries, there has been a substantial increase in generation of industrial wastewater, which is discharged either into open land or nearby aquatic ecosystem and caused environmental nuisance, if not properly treated before discharge. This activity promotes varying degree of pollution load in water, soil and air. Since the production of wastewater is a continuous process, it can cater for substantial irrigation requirements, where shortage of water becomes limiting factor (Banupriya and Gowrieb, 2012).

Agriculture is the major user of water and can accept marginal quality water without apparent loss of productivity or degrading soil and water qualities. It has unearthed agricultural potential of certain effluent and their probable use as irrigation source during fresh water scarcity, which are otherwise reported to defile natural resources and degrading the health of natural ecosystem. (Chauhan and Rai, 2010) reported that reuse of wastewater comprises organic and inorganic constituents that could meet nutrients requirement of crops, improve soil fertility, decrease the fertilizer and manure requirement.

Distilleries, one of the most important agro-based industries in India, produce ethyl alcohol from molasses for potable and industrial uses. The use of distillery waste water in agriculture is quite popular. In some water scarce areas, farmers are forced to use the effluent as a substitute for irrigation water but over the years its use has led to the realization of its fertilizer potential also. Various workers from their studies have suggested suitable application rates for distillery effluent for ferti-irrigation purposes and crop-specific nature of effluent. (Ramana et al., 2002; Kannan and Upreti, 2008; Malaviya and Sharma, 2011, Kumar and Chopra, 2010).

Solanum melongena is one of the most commonly grown vegetable crops of solanaceae family in India. India, China, Turkey, Japan, Philippines are the major egg plant production countries. In Uttarakhand hilly regions, it is grown only in summer. In popular medicine, eggplant is indicated for the treatment of several diseases including diabetes, arthritis, asthma and bronchitis. In addition, 
several groups have provided evidence that eggplant extracts have a significant effect in reducing blood and liver cholesterol rates in humans (Gandhar et al, 2011). In view of the above, various concentrations of DE and DAP were assessed for the specific fertility of the soil and for the growth, crop yield of S.melongena in order to understand their potential and to restore purity of the environment.

\section{MATERIALS AND METHODS}

Experimental design: A pot culture experiments were conducted in the Experimental garden of the Department of Zoology and Environmental Sciences, Gurukula Kangri University Haridwar $\left(29^{\circ} 55^{\prime} 10.81^{\prime \prime} \mathrm{N}\right.$ and $\left.78^{\circ} 07^{\prime} 08.12^{\prime \prime} \mathrm{E}\right)$ during the period March, 2011 to May, 2011. Poly bags $($ dia- $30 \mathrm{~cm})$ were used for growing the $S$. melongena plants. The pots were arranged in a completely randomized design. Twenty four poly bags were filled with soil and used for the cultivation of crops. Proper distance was maintained between each replicate $(30 \mathrm{~cm})$, between all treatments $(60 \mathrm{~cm})$ and plant to plant $(5 \mathrm{~cm})$. Each bag was made porous for aerating and was labelled for the various treatments viz. control, DAP, 10, 25, 50, 75 and $100 \%$ concentrations of distillery effluent.

Effluent collection and analysis: Doon Distillery Doiwala, Dehradun (Uttarakhand), India producing alcohol at the rate of $150 \mathrm{Kl}$ per day from agro based residue was selected for the collection of effluent. The effluent was collected in the plastic containers from the outlet of the secondary settling tank situated in the campus of the Distillery unit. The effluent was brought to the laboratory and then analysed for various physico-chemical and microbiological parameters viz. Total dissolved solids (TDS), electrical conductivity (EC), $\mathrm{pH}$, dissolved oxygen (DO), biological oxygen demand (BOD), chemical oxygen demand $(\mathrm{COD})$, Bicarbonate $\left(\mathrm{HCO}_{3}^{-}\right)$, total Kjheldal nitrogen (TKN), Phosphate $\left(\mathrm{PO}_{4}^{3-}\right)$, Potassium $\left(\mathrm{K}^{+}\right)$, calcium $\left(\mathrm{Ca}^{2+}\right)$, magnesium $\left(\mathrm{Mg}^{2+}\right)$, chloride $\left(\mathrm{Cl}^{-}\right)$, Sodium $\left(\mathrm{Na}^{+}\right)$, standard plate count (SPC), most probable number (MPN), fungi and actinomycetes following standard methods (APHA, 2005). The effluent was used as agrofertilizer for cultivation of $\mathrm{S}$. melongena at its different concentrations viz. 10, 25, 50, 75 and $100 \%$ made by diluting with bore well water (BWW) in comparison to DAP treatment.

Soil prepar ation, filling of bags, sampling and analysis: The soil used for cultivation was collected at a depth of $0-15 \mathrm{~cm}$. Each poly bag $(30 \times 30 \mathrm{~cm})$ was filled with $5 \mathrm{Kg}$ of well-prepared soil with a depth of $25 \mathrm{~cm}$, earlier air-dried and sieved to remove debris and mixed with equal quantity of farmyard manure. The research recommended rate (220 $\mathrm{kg} \mathrm{ha}^{-1}$ ) DAP for egg plant cultivation was followed. According to which $0.311 \mathrm{~g}$ DAP was applied to per bag (Suge et al 2011). The soil was analysed before sowing and after harvesting of the crop for various physicochemical parameters following standard methods for moisture content (MC) and EC (Buurman et al., 1996), for soil texture (Bouyoucos, 1962); and for bulk density (BD) and water holding capacity (WHC) (Carter, 1993). The soil $\mathrm{pH}$ was determined using a glass electrode and $\mathrm{pH}$ meter. The other parameters such as $\mathrm{Cl}^{-}$, Organic carbon(OC), exchangeable sodium $\left(\right.$ exc. $\left.\mathrm{Na}^{+}\right)$, available potassium $\left(\right.$ ava. $\mathrm{K}^{+}$), available phosphorus (ava.P), $\mathrm{Ca}^{2+}$, $\mathrm{Mg}^{2+}$, $\mathrm{TKN}$, and $\mathrm{SO}_{4}^{2-}$ were determined using standard methods (Chaturvedi and Sankar, 2006). Total bacteria, fungi and actinomycetes were determined using standard methods of Aneja (1996).

Sowing of seeds, irrigation pattern and collection of crop parameter data: The DE was applied at its dilutions of $10,25,50,75$ and $100 \%$ concentrations per $5 \mathrm{~kg}$ soil and then left for 2 weeks to allow for mineralization and further irrigation of the crop plant. The seeds of S. melongena (var. Pusa-Komal) were procured from ICAR, Pusa, New Delhi , India and sterilized with $0.01 \%$ mercuric chloride and soaked for $12 \mathrm{hrs}$. Eggplant is a transplanted vegetable; its seeds were sown, germinated and raised under greenhouse conditions in $1 \mathrm{~m}^{2}$ seedbed. When they had three real leaves, eggplant seedlings were transferred to polybags. Until the plants were established, they were irrigated with BWW. Four seedlings of egg plant were sown at equal distance of $5 \mathrm{~cm}$ in each bag and maintained for 60 days till the development of the plant. Each set was replicated six times as twenty four plants were grown for each treatment. The crops received the effluent at concentrations of $10,25,50,75$ and $100 \%$ as irrigant doses $(500 \mathrm{~mL})$ twice a week as per the requirement of crop plant and no drainage was allowed. The various agronomical parameters of S. melongena were noted after 60days by standard methods for seed germination viz. plant height, root length, number of leaves, number of flowers, number of fruits, fruit length, fruit diameter and crop yield (Chandrasekar et al., 1998); fruit weight (Milner and Hughes 1968), chlorophyll content (Porra, 2002) and for Leaf area (Karunyal et al., 1994).

Statistical analysis: One way analysis of variance (ANOVA) was used for data analysis to measure the variations between the soil parameters before and after irrigation of the crop with different DE concentrations. MS Excel, 2000 was used to measure the Standard deviation (SD) and coefficient of correlation ( $r$ value).

\section{RESULTS AND DISCUSSION}

Effluent characteristics: The mean \pm SD values of physico-chemical parameters of DE of Doon distillery, Doiwala (Dehradun) are given in Table 1.

The present study revealed that the effluent of Distillery Unit was acidic $(\mathrm{pH}-6.17 \pm 0.31)$ in nature. Among various parameters of DE, BOD $\left(1734.00 \pm 5.89 \mathrm{mgL}^{-1}\right), \mathrm{COD}$ 
$\left(2527.02 \pm 19.19 \mathrm{mgL}^{-1}\right) \mathrm{Cl}^{-}\left(848.90 \pm 10.46 \mathrm{mgL}^{-1}\right), \mathrm{Ca}^{2+}$ $\left(435.01 \pm 7.28 \mathrm{mgL}^{-1}\right) \mathrm{HCO}_{3}^{-}\left(964.83 \pm 15.03 \mathrm{mgL}^{-1}\right), \mathrm{TKN}$ $\left(477.85 \pm 6.90 \mathrm{mgL}^{-1}\right), \mathrm{PO}_{4}^{3-}\left(177.72 \pm 5.99 \mathrm{mgL}^{-1}\right), \mathrm{MPN}$ $\left(40.50 \times 10^{4} / 100 \mathrm{ml}^{-1}\right), \operatorname{SPC}\left(22.5 \times 10^{6} \mathrm{cfu} \mathrm{ml}^{-1}\right)$, fungi $(8.75$ $\left.\mathrm{x} 10^{4}\right)$ and actinomycetes $\left(7.50 \times 10^{5}\right)$ were beyond the prescribed limit of Indian irrigation standards (BIS, 1991) (Table 1).

The higher values of TDS, BOD and COD indicate that DE was loaded with organic and inorganic compounds that could bring remarkable changes on the physical, chemical and biological properties of the soil and thus influences the fertility of soil significantly as also indicted by Kalaiselvi and Mahimairaja (2010) for red gravelly clay soil at higher concentration.

Soil character istics: The mean \pm SD values of various physico-chemical and microbiological parameters viz. moisture content, $\mathrm{WHC}, \mathrm{BD}$, soil texture, $\mathrm{EC}, \mathrm{pH}, \mathrm{Cl}^{-}, \mathrm{OC}$, exc. $\mathrm{Na}^{+}$, ava. $\mathrm{K}^{+}, \mathrm{Ca}^{2+}, \mathrm{Mg}^{2+}$, TKN, $\mathrm{PO}_{4}^{3-}, \mathrm{SO}_{4}^{2-}$, total bacteria, fungi and actinomycetes of the soil before and after irrigation with different concentrations viz. $10 \%$, $25 \%, 50 \%, 75 \%$ and $100 \%$ of DE along with control (BWW) and DAP for 60 days are given in Table 2.

The present study showed that the soil irrigated with $100 \%$ DE dilutions showed remarkable increase in different parameters like moisture content (30.82\%), WHC (16.28\%), $\mathrm{BD}(9.72 \%), \mathrm{EC}(63.46 \%), \mathrm{Cl}^{-}(292.37 \%), \mathrm{OC}(3763.63 \%)$, exc. $\mathrm{Na}^{+}(264.29 \%)$, ava. $\mathrm{K}^{+}(48.39 \%), \mathrm{Ca}^{2+}(+815.74 \%)$, $\mathrm{Mg}^{2+}(+1162.72 \%), \mathrm{TKN}(+1449.18 \%)$, Ava. $\mathrm{P}(+338.83 \%)$, and $\mathrm{SO}_{4}^{2-}(+80.07 \%)$, while there was a decrease in $\mathrm{pH}$ $(-17.85 \%)$, fungi $(-52.17 \%)$, total bacteria $(-48.64 \%)$ and actinomycetes $(-78.00 \%)$. The earlier studies also reported an increase for EC $(1.85 \mathrm{dS} / \mathrm{m}), \mathrm{TOC}(1.9 \%)$, TKN $(0.20 \%)$, ava.P $(0.06 \%)$, Exc. $\mathrm{Na}(4 \%), \mathrm{Ca}(0.31 \%)$, Ava. $\mathrm{K}^{+}(4.9 \%)$ and $\mathrm{Cl}^{-}(0.03 \%)$ on irrigation of pearl millet with DE in sodic soil for 30 days at $100 \%$ concentration (Kaushik et al.,2005); and for EC $(11.0 \mathrm{dS} / \mathrm{m}), \mathrm{OC}(0.67 \%), \mathrm{K}^{+}(5 \mathrm{mg}$ $\left.\mathrm{kg}^{-1}\right), \mathrm{Na}^{+}\left(1026 \mathrm{mg} \mathrm{kg}^{-1}\right), \mathrm{Ca}^{2+}\left(574 \mathrm{mg} \mathrm{kg}^{-1}\right), \mathrm{Mg}^{2+}(203 \mathrm{mg}$ $\left.\mathrm{kg}^{-1}\right), \mathrm{Cl}\left(1372 \mathrm{mg} \mathrm{kg}^{-1}\right)$, and $\mathrm{SO}_{4}^{2-}\left(1050 \mathrm{mg} \mathrm{kg}^{-1}\right)$ in sodic soil irrigated with DE at higher concentration (Sindhu et al. (2007).

$\mathrm{pH}$ is an essential parameter as many nutrients are available only at a particular range of $\mathrm{pH}$ for plant uptake. The earlier studies reported that a $\mathrm{pH}$ range of 6.0 to 8.3 enhanced the nutrient availability for the growth of plants and change in $\mathrm{pH}$ beyond this limit (below 6.0 and above 8.3) inhibited the availability of nutrients; affect the rate of biological reaction and survival of various microorganisms in the soil for the growth of plants (Charman and Murphy, 2000; Brady and Weil, 2005). In the present study, $\mathrm{pH}(6.35 \pm 0.38)$ of the soil at $100 \% \mathrm{DE}$ concentration was recorded to be within range, which may help in enhancing the various nutrients of the soil. It has been reported that the higher values of EC in DE irrigated soil indicate enrichment of soluble cations and anions such as $\mathrm{Cl}^{-}, \mathrm{PO}_{4}^{3-}, \mathrm{SO}_{4}^{2-}, \mathrm{Mg}^{2+}$, exc. $\mathrm{Na}^{+}$, ava. $\mathrm{K}^{+}$ and $\mathrm{Ca}^{+}$through the incessant use of effluent in different concentrations, which stimulate the growth at lower concentration but inhibit at higher concentration (Patterson et al., 2008; Kumar et al., 2010). In the present study, there was a maximumincrease in the EC $(3.4 \pm 0.13$ $\mathrm{dS} \mathrm{m} \mathrm{m}^{-1}$ ) of soil as the concentration of DE increased up to $100 \%$. This might be due to increase in concentration of potassium salts which is mainly responsible for increasing the EC of the DE as also reported by Sindhu et al. (2007) sodic soil. The moisture content and overall water content in soil are governed by the amount of water coming and going out from the soil. Presence of large soil particles reduces the soil moisture content (Miller and Turk, 2002). In the present study moisture content was recorded to be increased. WHC is related to the number and size distribution of soil pores and consequently increases with soil organic matter level. It is related to soil moisture content, textural class, structure, salt content and organic matter (Ramulu, 2001), while BD of the soil changes with land use and management practices. The low content of organic matter in the effluent and the efficient filtration by the sand may bring slight change in BD of soil in southern Iran as reported by Ali et al. (2008). In the present study, BD and WHC of soil irrigated with DE showed a slight increase at $100 \%$ concentration of the effluent indicating significant impact of DE on the soil of the area. A significant increase $(\mathrm{P}<$ 0.001) was recorded in the TOC, TKN, $\mathrm{Ca}^{2+}$ and $\mathrm{Mg}^{2+}$ content of the soil on irrigation with $100 \%$ DE concentration. This might be attributed to higher organic load of DE. Similarly, early study on soil irrigated with DE also showed an increase for these parameters as reported by Kumar and Chopra (2011b) for sandy loam soil.

The higher concentration of exc. $\mathrm{Na}^{+}$in soil after effluent irrigation may be associated with the presence of high concentration of bicarbonates in the effluent. In the present study concentration of $\mathrm{Cl}^{-}$and $\mathrm{SO}_{4}{ }^{2-}$ was also recorded to be higher in soil irrigated with $100 \%$ concentration of DE. Effluent irrigation adds a significant quantity of salts to the soil such as sulphates and chlorides that stimulate the growth at lower concentration, but inhibits the growth at higher concentrations (Patterson et al., 2008). Shenbagavalli et al. (2011) reported that $\mathrm{Cl}^{-}$and $\mathrm{SO}_{4}{ }^{2-}$ were relatively higher in the fields that received distillery spentwash. The occurrence of $\mathrm{Cl}^{-}$ions in spentwash increases with the increase in EC. These two anions significantly contributed towards the salinity hazards associated with water for irrigation. The present study recorded maximum concentration of ava. $\mathrm{P}$ and ava. $\mathrm{K}^{+}$contents in the soil. This might be due to increase in mineralization activity of organic matter as well as nutrients present in DE that may be responsible for increased availability of plant nutrients. Chidankumar 
Table 1. Physico-chemical, heavy metal and microbiological characteristics of Doon Distillery effluent Doiwala, Dehradoon (Uttarakhand).

\begin{tabular}{|c|c|c|c|}
\hline Parameter & $\begin{array}{c}\text { BWW } \\
\text { irrigation }\end{array}$ & DE irrigation & $\begin{array}{c}\text { BIS for } \\
\text { irrigation water }\end{array}$ \\
\hline TDS $\left(\mathrm{mg} \mathrm{L}^{-1}\right)$ & $201.55 \pm 7.91$ & $1443.86 \pm 102.89$ & 1900 \\
\hline $\mathrm{EC}\left(\mathrm{dS} \mathrm{m^{-1 }}\right)$ & $1.10 \pm 0.03$ & $15.47 \pm 2.40$ & - \\
\hline $\mathrm{pH}$ & $7.51 \pm 0.19$ & $6.17 \pm 0.31$ & $5.5-9.0$ \\
\hline $\mathrm{BOD}\left(\mathrm{mg} \mathrm{L}^{-1}\right)$ & $4.20 \pm 0.48$ & $1734.00 \pm 5.89$ & 100 \\
\hline $\mathrm{COD}\left(\mathrm{mg} \mathrm{L}^{-1}\right)$ & $18.18 \pm 0.65$ & $2527.02 \pm 19.19$ & 250 \\
\hline $\mathrm{Cl}^{-}\left(\mathrm{mg} \mathrm{L}^{-1}\right)$ & $15.78 \pm 1.30$ & $848.90 \pm 10.46$ & 500 \\
\hline $\mathrm{HCO}_{3}^{-}\left(\mathrm{mg} \mathrm{L}^{-1}\right)$ & $252.88 \pm 5.65$ & $964.83 \pm 15.03$ & 450 \\
\hline $\mathrm{Ca}^{2+}\left(\mathrm{mg} \mathrm{L}^{-1}\right)$ & $22.54 \pm 1.38$ & $435.01 \pm 7.28$ & 200 \\
\hline $\mathrm{Mg}^{2+}\left(\mathrm{mg} \mathrm{L}^{-1}\right)$ & $12.39 \pm 1.12$ & $153.43 \pm 11.69$ & - \\
\hline $\mathrm{TKN}\left(\mathrm{mg} \mathrm{L}^{-1}\right)$ & $24.75 \pm 1.69$ & $477.85 \pm 6.90$ & 100 \\
\hline $\mathrm{PO}_{4}{ }^{3-}\left(\mathrm{mg} \mathrm{L}^{-1}\right)$ & $0.15 \pm 0.05$ & $177.72 \pm 5.99$ & - \\
\hline $\mathrm{SO}_{4}{ }^{2-}\left(\mathrm{mg} \mathrm{L}^{-1}\right)$ & $128.25 \pm 4.21$ & $650.37 \pm 10.69$ & 1000 \\
\hline $\mathrm{SPC}\left(\mathrm{SPC}\right.$ cfu ml $\left.{ }^{-1}\right)$ & $69.50 \pm 7.59$ & $22.25 \times 10^{6}$ & - \\
\hline MPN (MPN100 ml ${ }^{-1}$ ) & $12.50 \pm 4.56$ & $40.5 \times 10^{4}$ & 5000 \\
\hline Fungi $\left(\mathrm{cfu} \mathrm{ml}^{-1}\right)$ & $2.36 \times 10^{4}$ & $8.75 \times 10^{4}$ & - \\
\hline Actinomycetes $\left(\mathrm{cfu} \mathrm{ml}^{-1}\right)$ & $2.07 \times 10^{5}$ & $7.50 \times 10^{5}$ & - \\
\hline
\end{tabular}

Mean \pm SD of four values; BWW - Borewell water; BIS- Bureau of Indian standards

et al., (2009) also reported an increase for these parameters in experimental soil irrigated with distillery spentwash at higher concentration on the yield of creepers.

Soil microbes play an important role in maintaining the fertility of soil. It is reported that the distillery spentwash possesses the microbial population particularly bacteria, fungi and actinomycetes in appreciable amount (Suganya and Rajanan, 2009). The present study was showed maximum population of bacteria at $50 \%$ concentration of DE irrigated soil, whereas fungi and actinomycetes were maximum at $25 \%$ concentration of DE irrigated soil. After this dilution, a declining trend was observed in the population of all these soil microbes. Earlier studies on these soil microbes also reported greater toxicity of raw distillery wastewater to soil microflora (bacteria, fungi and actinomycetes), which was minimized after dilution of the effluent. This might be due to high dose of the effluent that may have some inhibitory effects on microbial activity due to higher concentration of salts, or some organic acids as suggested by (Juwarkar et al., 1990). Jothimani et al. (2002) reported that bacteria, fungi and actinomycetes in soil grown with cowpea and maize seedlings recorded a decreasing trend with corresponding increase in dye effluent concentration. Higher population was found at lower concentration of $25 \%$ and $50 \%$. Reduction in microbial population at higher effluent concentration may be due to reverse osmosis which reduced the moisture level of soil, an important factor that favours microbial growth.

Chandra et al. (2004) reported that the irrigation of the pots by $1-10 \%$ distillery effluent stimulated the growth of the soil microflora (bacteria, fungi and actinomycetes) and $P$. aureus plants (shoot and root length, biomass and chlorophyll content). Further, 15-20\% distillery effluent had toxic effect on soil micro flora as indicated by reduced number of bacteria, fungi and actinomycetes. In the present study all the mean yield of the physicchemical soil amendments were in the order of $100 \% \mathrm{DE}$ concentration > DAP > BWW except soil microflora in which bacteria were recorded maximum at $50 \%$ concentration of DE irrigated soil, while fungi and actinomycetes at 25\% concentration of DE irrigated soil as compared to DAP treatment and BWW treatment.

The coefficient of correlation on soil characteristics revealed that moisture content, $\mathrm{BD}, \mathrm{WHC}, \mathrm{EC}, \mathrm{Cl}$ ", TOC, exc. $\mathrm{Na}^{+}$, ava. $\mathrm{K}^{+}, \mathrm{Ca}^{2+}, \mathrm{Mg}^{2+}$, TKN, ava.P and $\mathrm{SO}_{4}^{2-}$ were positively correlated with all $\mathrm{DE}$ concentrations, while $\mathrm{pH}$, total bacteria, fungi and actinomycetes were negatively correlated. The ANOVA showed that different dilutions of DE affected differently on various nutrients. Among the soil parameters $\mathrm{pH}, \mathrm{Cl}^{-}$, ava. $\mathrm{K}^{+}, \mathrm{Ca}^{2+}, \mathrm{TKN}$, ava.P, $\mathrm{Mg}^{2+}$, Exc. $\mathrm{Na}^{+}$and $\mathrm{TOC}$, total bacteria, actinomycetes and $\mathrm{SO}_{4}^{2-}$ were found to be significantly $(\mathrm{P}<0.001)$ affected with different $\mathrm{DE}$ concentrations $(10 \%$ to $100 \%$ ) as compared to control and DAP, while soil moisture content and fungi were significantly $(\mathrm{P}<0.01)$ affected with $25 \%$ to $100 \%$ DE concentrations as compared to control and DAP. EC was also significantly $(\mathrm{P}<0.05)$ affected. However, the BD and WHC were found to be non- significantly ( $P>0.05)$ affected with 


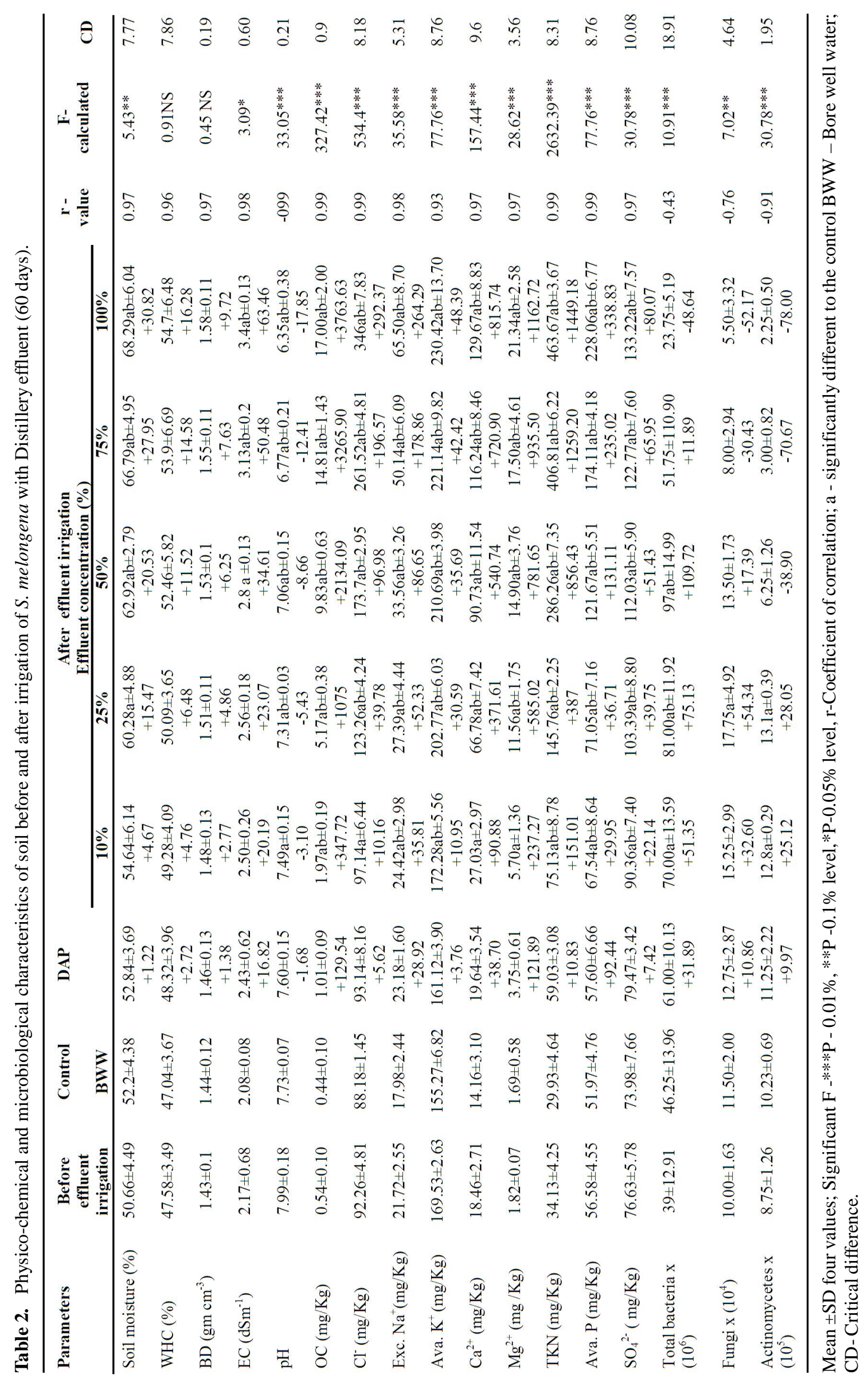




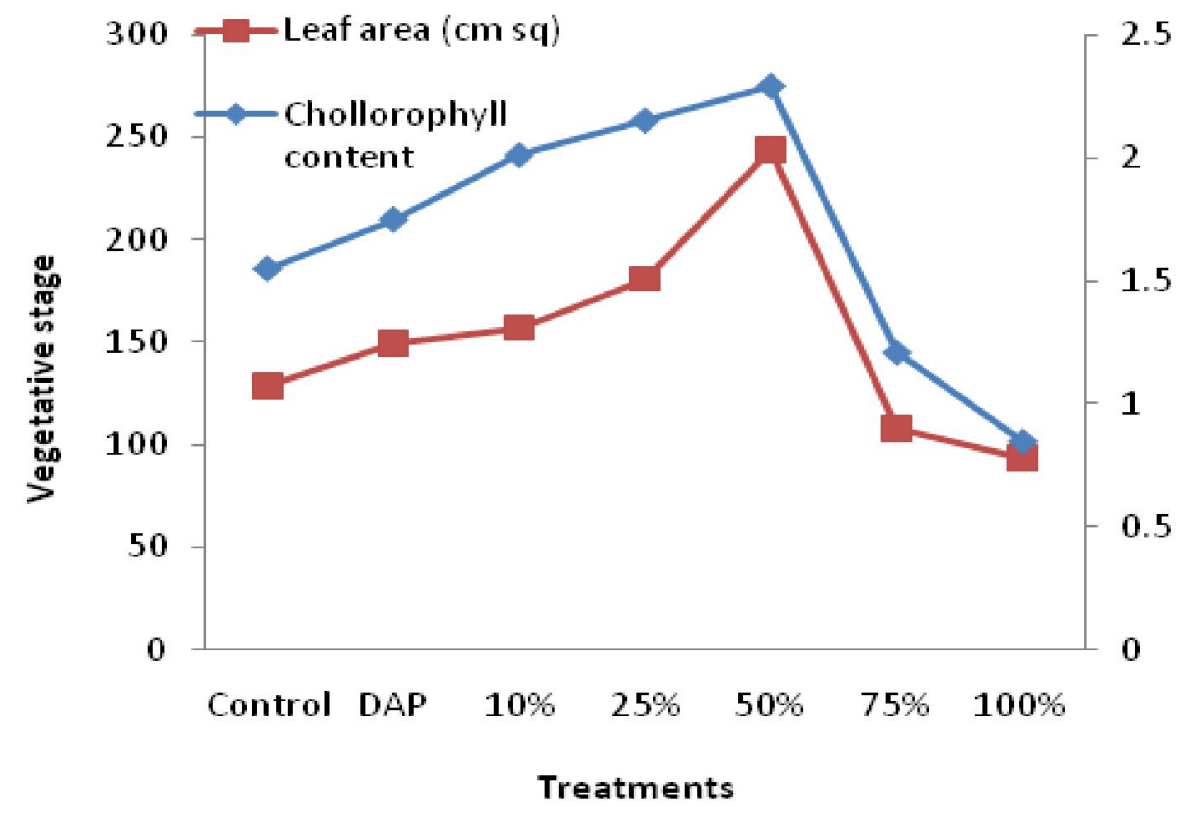

Fig. 1. Vegetative growth stage of S. melongena after irrigation with D istillery effluent.

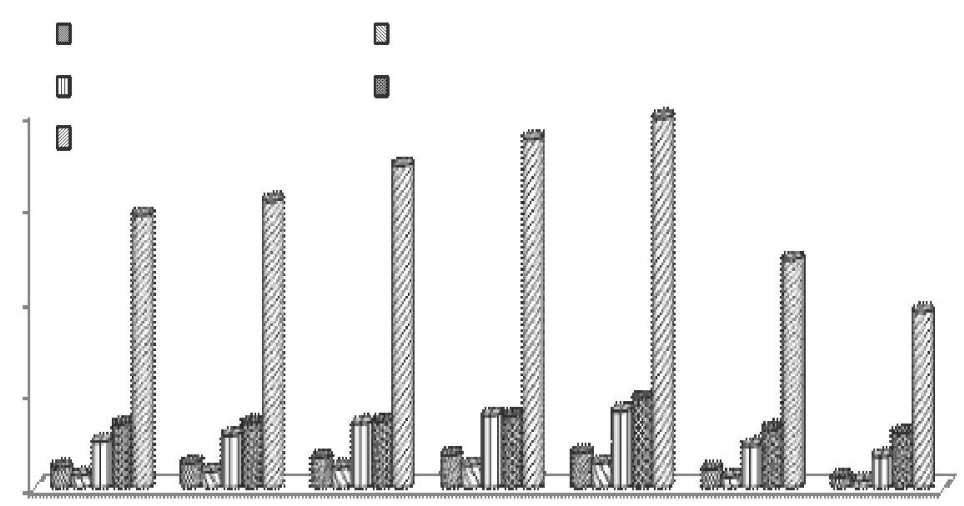

Fig.2. Flowering and fruiting stage of $\mathrm{S}$. melongena after irrigation with $\mathrm{D}$ istillery effluent.

different dilutions of DE (Table 2).

A gronomical char acter istics: All stages of S. melongena such as vegetative growth stage, flowering and fruiting stage and maturity stage with different concentrations of DE along with control and DAP are shown in Figs.1-3). Vegetative growth stage: It has been observed that combined (distillery and sugar mill) effluent stimulates chlorophyll content of barley at $25 \%$ and $50 \%$ concentrations, but showed decrease at $75 \%$ and $100 \%$ concentrations of effluent mixture in comparison to control. The total chlorophyll contents were significantly altered in barley in all the treatments (Nath et al., 2007). In the present study chlorophyll content of $\mathrm{S}$. melongena was recorded maximum at $25 \%$ concentration of DE as compared to BWW and DAP. The chlorophyll content ( $\mathrm{r}$ $=-0.77$ ) indicates that it decreased with increase in effluent concentrations. This is due to irrigation of $S$. melongena plants with DE which impairs the soil productivity and inhibits the population and biological activities of soil microbes at higher concentrations. Similar findings have been reported by Karunyal et al., (1994), who reported increased chlorophyll content in L.esculentum, G.hirsutum, V.unguiculata and V.mungo at $25 \%$ concentration of tannery effluent. Reduction of chlorophyll pigment at higher concentration (100\%) may be associated with mineral ions. Some of the possible reasons for the decrease of pigment contents may be due to the formation of enzyme chlorophyllase, which is responsible for chlorophyll degradation as reported by Rath et al. (2011). Chlorophyll content in crops also suggest that the synthesis of chlorophyll is accelerated at lower concentrations of effluent that provides lower quantities of heavy toxic metals in the diluted effluent and probably increase the availability of $\mathrm{Fe}$ and $\mathrm{Mg}$ which 


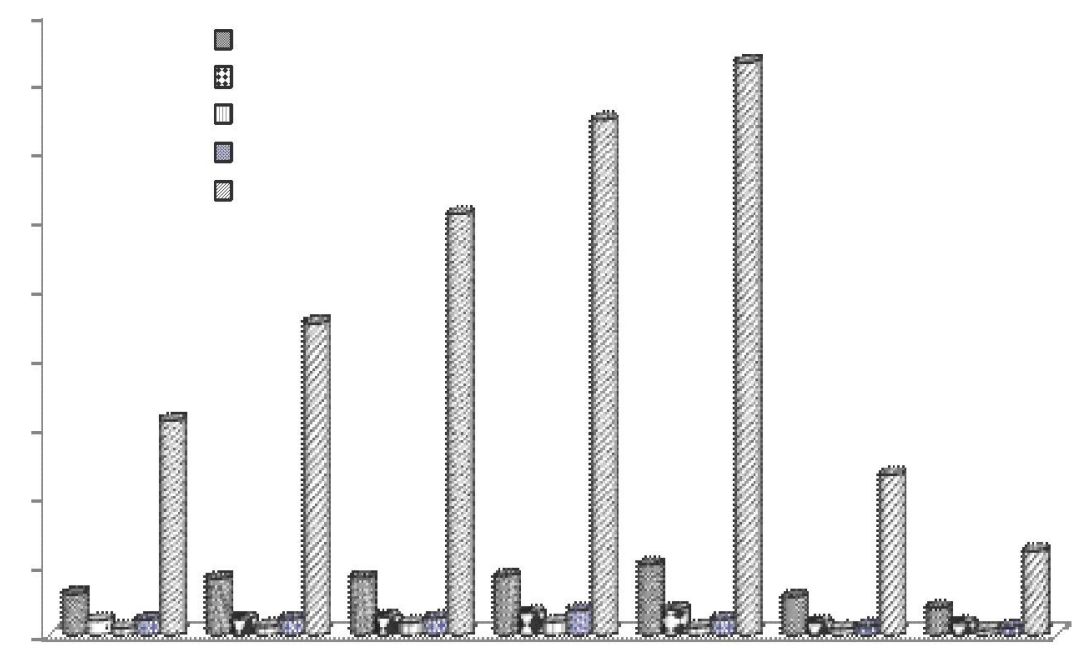

Fig.3. M aturity stage of S. melongena after irrigation with $D$ istillery effluent.

are necessary for the synthesis of chlorophyll. The lower DE concentrations initiates speedy transformation of magnesium, ava. $\mathrm{K}^{+}$and exc. $\mathrm{Na}^{+}, \mathrm{Ca}^{2+}, \mathrm{N}$ and $\mathrm{So}_{4}{ }_{4}^{2-}$ to the crops as reported in earlier studies done by (Baghel et al., 2008; Kumar and Chopra, 2011a) for other crops.

In the present study leaf area $\left(\mathrm{cm}^{2}\right)$ of S.melongena was recorded at $50 \%$ concentration of DE. This might be due to lower concentration of $\mathrm{DE}$, which provides proper nutrients for positive growth response of S.melongena. Karunyal et al., (1994) reported that leaf area $\left(\mathrm{cm}^{2}\right)$ of $\mathrm{G}$. hirsutum, V. mungo, V. uniquiclata and L. esculentum, increased at $25 \%$ concentration of Tannery effluent, when effluent was diluted with water. Chandra et al, (2002) reported that metabolic process in plants and water absorption in soil was possibly affected due to excess of nitrogen, phosphate, potassium, sulphate, calcium, and chloride at higher concentration of the DE. Pandey et al., (2008) also showed that leaf area of wheat plant was achieved at $50 \%$ concentration of DE due to availability of nutrients in required amount.

Flowering and fruiting stage: In the present study number of flowers/plant, number of fruits/plant and fruit length/plant, fruit diameter/plant and fruit weight/plant of $\mathrm{S}$. melongena were found maximum at $50 \%$ concentration of DE as compared to BWW and DAP. The correlation for flowers/plant $(\mathrm{r}=-0.57)$, number of fruits/plant $(r=-0.51)$, fruit length/plant $(r=-0.52)$, fruit diameter/plant $(\mathrm{r}=-0.31)$ and fruit weight/plant $(\mathrm{r}=-0.64)$ indicated a negative correlation with DE concentrations. The lower concentration of DE showed better performance on flowering and fruiting stage of the crop which might be due to the maximum absorption of plant nutrients like $\mathrm{N}, \mathrm{P}$ and $\mathrm{K}$. Its use for irrigation at appropriate concentrations enriches the soil fertility.
(Nath et al., 2007) reported that lower concentrations of DE provide predominating salt amount, which in turn shapes plant growth and development. Kumar and Chopra, (2010) recorded the maximum number of flowers/ plant, number of pods/plant and pod length/plant in Trigonella foenum-graecum irrigated has been shown with $25 \%$ concentration of paper mill effluent. Similar findings had been observed by Malaviya and Sharma, 2011 also recorded that number of siliqua, average siliqua length and total weight of siliqua per plant was found to be maximum in $20 \%$ distillery effluent and minimum in $100 \%$ DE concentration.

M aturity stage: The plant height/plant, root length/ plant, number of leaves/plant and crop yield of $S$. melongena were recorded maximum at $50 \%$ concentration of DE as compared to BWW and DAP treatment. The correlation for plant height /plant $(r=-0.49)$, root length/ plant $(r=-0.38)$, number of leaves/plant $(r=-0.71)$ and crop yield $(r=-0.49)$ of $S$. melongena indicated negative correlation with different dilutions of DE. The positive response on these parameters at lower concentration of DE might be probably due to action of effluent acting as liquid manurial fertilizer at lower concentration. The higher concentration of DE retarded the growth. Thus, it had both stimulatory and inhibitory effects on the maturity stage of growth of seedlings as also reported by Nath et al., (2007) for wheat, garden pea, black gram and mustard and by Pandey et al., (2008) for maize and rice.

Ramana et al., (2002) reported maximum growth and yield at lower concentration that might be due to the significant addition of various salts such as nitrogen, phosphorus and potassium from effluent to the soil and mineralization through microbes at lower dilution. Chandraju et al., (2010) also reported that the growth, yield and nutrients were 
more in the case of $33 \%$ than $50 \%$ distillery spent wash and raw distillery spent wash irrigations for all varieties of leafy vegetables. This concludes that diluted spentwash can be conveniently used for cultivation of leafy vegetables. Lower dilution levels of DE resulted in higher amounts of residual nutrients ability, due to lesser uptake by crops and irrigation by undiluted $\mathrm{DE}$ resulted in drastic reduction in the yield of crop due to toxic effect of DE as reported by Sukanya and Meli, (2004) for the wheat crop. The ANOVA analysis of data showed that root length, chlorophyll content, leaf area, number of flowers, fruit weight, number of fruits and crop yield of S. melongena were found to be significantly $(\mathrm{P}<0.001)$ affected with $10 \%$ concentrations of DE in comparison to BWW, whereas these parameters were also found to be significantly $(\mathrm{P}<0.001)$ affected with $25 \%$ and $50 \%$ concentrations of DE. Number of leaves and fruit diameter were significantly $(\mathrm{P}<0.001)$ affected at $25 \%$ in comparison to BWW, whereas with $50 \%$ DE concentration they were significantly $(\mathrm{P}<0.001)$ affected with both BWW and DAP respectively. Plant height was significantly $(\mathrm{P}<0.001)$ affected at both $10 \%$ and $25 \%$ concentrations of DE in in comparison to $\mathrm{BWW}$, whereas at $50 \% \mathrm{DE}$ concentration it was significantly $(\mathrm{P}<0.001)$ affected with both $\mathrm{BWW}$ and DAP. Number of branches was significantly $(\mathrm{P}<0.001)$ affected at both $25 \%$ and $50 \%$ concentrations of DE in in comparison to BWW and DAP, whereas fruit length was significantly $(\mathrm{P}<0.001)$ affected at $10 \%, 25 \%$ and $50 \%$ concentrations of DE in in comparison to BWW and DAP.

\section{Conclusion}

The present study concluded that DE had a considerable effect on soil properties. It increased the, moisture content; WHC, BD, EC, Cl", TOC, exc. $\mathrm{Na}^{+}$, ava. $\mathrm{K}^{+}, \mathrm{Ca}^{2+}$, $\mathrm{Mg}^{2+}$, TKN, ava. $\mathrm{P}_{\text {and }} \mathrm{SO}_{4}^{2-}$ of the soil to a certain level with dilution of $\mathrm{DE}$, whereas $\mathrm{pH}$, bacteria, fungi and actinomycetes were decreased. Among various dilutions of DE, irrigation with $50 \%$ dilution of DE concentration improved the soil nutrient and micro flora status that resulted in the maximum growth performance of $S$. melongena plants in comparison to DAP and BWW. It may be due to the low nutrient accumulation in the soil at this concentration, which might have stimulated the growth performance of the crop. It was more economical than that of DAP treatment in the cultivation of $S$. melongena plants. It acts as ferti- irrigant in the form of plant nutrients which provide agro potentiality to the plant. Thus, $50 \%$ dilution of DE can be conveniently used for the effectual cultivation without using any other external fertilizers and water for enhancing the crop productivity.

\section{REFERENCES}

Ali, M. H., Mahmood, J. and Yusof, S. (2008). Reuse of municipal effluent with drip irrigation and evaluate the effect on soil properties in a semi-arid area. Environmental monitoring and Assessment, 144: 151-158.

APHA (2005). Standard methods for the examination of water and wastewater (21st Edn.). Washington, D.C., American Public Health Association.

Aneja, K.R. (1996). Experiments in microbiology plant pathology tissue culture and mushroom cultivation $\left(2^{\text {nd }}\right.$ edition) WishwaPrakashan (New age international private limited) ISBN: 81-7328-082-7.

Baghel, R.S. (2008).Toxicity of distillery effluent on seed germination, seedling growth and metabolism in Pisum sativum. Research journal of environment and Life Science, 1 (1), 29-32.

Banupriya, G. and Gowrieb, S.U. (2012) A study on microbial diversity of dairy effluent and its impact on growth of different plant species. INT J CURR SCI, New Liberty Group, 71-77.

BIS (1991). Indian standards for drinking water specification (BIS 10500:1991). http:// www.bis.org.in, retrieved on 20 April 2007.

Bouyoucos, G. J. (1962). Hydrometer method improved for making particle size analysis of soils. Agronomy J ournal, 54: 464 .

Brady, N.C. and Weil, R.R. (2005). The nature and properties of soils, 13th Ed. Delhi: Pearson Education.

Buurman, P. B., Van, L. and Velthrost, E. J. (1996). M anual of soil and water analysis. Leiden, The Netherland: Backhuys Publisher.

Carter, M.R. (1993). Soil sampling and method of analysis, Lewis Publishers, Boca Raton, FL: Lewis Publishers.

Chandra, R., Kumar, K. and Singh, J. (2004). Impact of anaerobically treated and untreated (raw) distillery effluent irrigation on soil microflora, growth, total chlorophyll and protein contents of Phaseolus aureus L. J. Environ. Biol. 25(4):381-5.

Chandra, S., Joshi, H.C., Pathak, H., Jain, M.C. and Kalra, N. (2002). Effect of potassium salts and distillery effluent on carbon mineralization in soil. Bioresource Technology; 83(3): 255-257.

Chandraju, S., Chidankumar, C. S and Venkatachalapathy, R. (2010). Irrigational impact of distillery spentwash on the growth, yield and nutrients of leafy vegetables. Bioresearch Bulletin, (2) 83-90.

Chandrasekar, N., Subramani, A. and Saravana, S. (1998). Effect of sugar mill effluent on germination and early seeding growth of black gram (Vigna mungo (L) Hepper Var. ADT-3). Industrial Pollution Control, 14, 73-78.

Charman, P.E.V. and Murphy, B.W. (2000). Soils, their properties and management. In a soil conservation handbook for New South Wales. Sydney University Press. Sydney, 464.

Chaturvedi, R. K. and Sankar, K. (2006). Laboratory manual for the physico-chemical analysis of soil, water and plant (p. 97). Dehradun: Wildlife Institute of India.

Chauhan, J. and Rai, J. P. N. (2010). Monitoring of impact of ferti-irrigation by post-methanated distillery effluent on groundwater quality Clean - Soil, Air, Water, 38 (7), 630638.

Chidankumar, C.S., Chandraju S. and Nagendraswamy, R. (2009). Impact of distillery spentwash irrigation on the yields of top vegetables (Creepers) World applied sciences 
journal, 6 (9), 1270-1273.

Das, M., Singhandhupe, R.B., Chakraborty, H., Kumar, A., and Kanan, K. (2009). Reuse of industrial effluent water prospect and oppourtunities in agriculture perspectives. Research bulletin 46, Directorate of water management, Indian council of agriculture research, Bhubaneswar.

FAO - Review of World Water Resources by Country, (2003). Water Reports 23, Food and Agriculture Organization of the United Nations FAO, Rome, Italy, pp. 110.

Gandhar, T.U., Venkateshwarlu, M., Imran, M.A., Shekhar, G.P.Vand Reddy, K .J. M. (2011). Genetic transformation of agronomical important plant Solanum melongena L. through hypocotyl explant. Plant Sciences F eed - 1 (7): 142-146.

Jothimani, P., Prabakaran., J. and Bhaskaran A. (2002). Characterization and impact of dyeing factory effluent on germination and growth of maize and cowpea. M adras Agric. I., 89(10-12): 568-571.

Juwarkar, A. and Dutta, S. A. (1990). Impact of distillery effluent application to land on soil microflora. Environmental M onitoring and Assessment,15(2): 201-210.

Kalaiselvi, P. and Mahimairaja, S. 2010. Effect of spentwash application on nitrogen dynamics in soil. International J ournal of Environmental Science and Development, 1(2).

Kannan, A. and R.K. Upreti (2008). Influence of distillery effluent on germination and growth of mung bean (Vigna radiata) seeds. J .H azardous M aterials, 153: 609-615.

Karunyal, S., Renuga, G. and Paliwal, K. (1994). Effect of tannery effluent on seed germination, leaf area, biomass and mineral content of some plants. Bioresource Technol., 47: 215-218.

Kaushik, A., Nisha, R., Jagjeeta, K. and Kaushik, C.P. (2005). Impact of long and short term irrigation of a sodic soil with distillery effluent in combination with bioamendments. Bioresource Technology, 96(17) : 1860-1866.

Kumar, V. and Chopra, A. K. (2011b). Impact on physicochemical characteristics of soil after irrigation with distillery effluent. Archieves of A pplied Science and Research, 3 (4): 63-77.

Kumar, V. and Chopra, A.K. (2011a). Fertigation effect of distillery effluent on agronomical practices of Trigonella foenum-graecum L.(Fenugreek). E nvironment monitoring assessesment, DOI 10.1007/s10661-011-2033-7.

Kumar, V., Chopra, A.K., Pathak, C. and Pathak, S. (2010). Agro-potentiality of paper mill effluent on the characteristics of Trigonella foenum-graecum L. (Fenugreek). New York Science J ournal, 3 (5), 68-77.

Malaviya, P. and Sharma, A. (2011). Effect of distillery effluent on yield attributes of Brassica napus L. J . Environ. Biol., 32: 385-389.

Miller, C.E. and Turk, L.M. (2002). Fundamentals of soil science. Trinagar, 157.

Milner, C. and Hughes, R.E. (1968). Methods for the measur ement of primary production of grassland. IBP Hand Book No.6 Blackwell Sci. Pub. Oxford, England, 82.

Nath, K., Dharam, S. and Sharma, Y. K. (2007). Combinatorial effects of distillery and sugar factory effluents in crop plants. J ournal of Environmental Biology, 28 (3), 577-582.

Pandey, S.N., Nautiyal, B.D. and Sharma, C.P. (2008). Pollution level in distillery effluent and its phytotoxic effect on seed germination and early growth of maize and rice. J ournal of E nvironmental Biology, 29 (2), 267-270.

Patterson, S.J., Chanasyk, D.S., Mapfumo, E. and Naeth, M.A. (2008). Effects of diluted Kraft pulp mill effluent on hybrid poplar and soil chemical properties. Irrigation Science, 26, 547-560.

Porra, R.J (2002). The chequered history of the development $\&$ use of simultaneous equations for the accurate determination of chlorophylls $a$ and $b$. Photosynthesis Research, 73: 149 -156.

Ramana, S., Biswas, A.K., Kundu, S., Saha, J.K. and Yadava, R.B.R. (2002b). Effect of distillery effluent on seed germination in some vegetable crops. Biores. Technol., 82: 1189-1193.

Ramana, S., Biswas, A.K., Singh, A.B. and Yadava, R.B.R. (2002). Relative efficacy of distillery effluents on growth, nitrogen fixation and yield of groundnut. Bioresource Technology, 81: 117-121.

Ramulu Sree, U.S. (2001).Reuse of municipal sewage and sludge in agriculture. Scientific publishers (India), Jodhpur, 86.

Rath, P., Pradhan, G.. and Misra, M.K. (2011). Effect of distillery spentwash (DSW) and fertilizer on growth and chlorophyll content of sugarcane (Saccharum officinarum L.) plant. Recent Research in Science and Technology, 3 (4), 169-176.

Shenbagavalli, S., Mahimairaja, S. and Kalaiselvi, P. (2011). Impact of biomethanated distillery spentwash application on soil and water quality: A field appraisal. International J ournal of Environmental Sciences, 1-7.

Sindhu, S. K., Sharma, A. and Ikram, S. (2007). Analysis and recommendation of agriculture use of distillery spentwash in Rampur district, India. E-J ournal of Chemistry, 4 (3): 390-396.

Suganya, K. and Rajanan, G. (2009). Effect of one time postsown and pre-sown application of distillery spentwash on the growth and yield of maize crop. Botany Reasearch International 2(4): 288-294.

Suge, J.K., Omunyin, M.E. and Omami, E. N. (2011). Effect of organic and inorganic sources of fertilizer on growth, yield and fruit quality of eggplant (Solanum Melongena L). Archives of Applied Science Research, 3 (6):470-479.

Sukanya, T.S. and Meli, S.S. (2004). Response of wheat to graded dilution of liquid distillery Effluent (Spent wash) on plant nutrient contents, nutrient Uptake, crop yield and residual soil fertility. Karnataka J ournal of Agricultural Science, 17(3): 417-420. 